\title{
PENGARUH PENAMBAHAN LIMBAH PLASTIK JENIS THERMOSETTING TERHADAP PARAMETER MARSHALL LASTON AC-WC
}

\author{
Kusdiyono $^{1, *)}$, Supriyadi ${ }^{1)}$, Tedjo Mulyono ${ }^{1)}$, Sukoyo $^{1)}$ \\ ${ }^{1)}$ Jurusan Teknik Sipil Politeknik Negeri Semarang \\ Jl. Prof H. Sudarto, S.H. Tembalang Semarang 50275 \\ ${ }^{*}$ Email: kusdiyono110456@gmail.com
}

\begin{abstract}
At present, plastic is a material that is needed by the community at large, where the impact is also very extraordinary after the plastic is used in everyday life which can cause serious problems if the management is not done properly. The problem of plastic waste does not only occur in the city of Semarang, but also in other cities, so that the Ministry of Environment and Forestry has implemented a paid plastic bag program in the short term. But this is only to deal with problems in the short term. In the long run, it will not solve the problem of "plastic waste", because the policy actually encourages people to buy plastic which, of course, will add a new burden for the community to buy it. Based on the above problems, it is necessary to utilize this plastic waste to be made into road pavement materials such as in the manufacture of Asphal Concrette Wearing Course, by making 5 mixed variations ranging from (2 to 10)\% of the weight of the aggregate. This research was initiated through a survey process, material procurement, testing of stacking materials, making test specimens, testing specimens. The results of the research can show that the type of Thermosetting plastic waste has a significant influence on the Asphalt Concrete mixture AC-WC heat mixture, including: Density, Marshall Stability, Flow, VIM, VMA, MQ and the remaining Marshall Stability tend to show an increase, moderate VFA and VIMrefusal Density values tend to show a decrease. Thus the plastic waste from the Thermosetting type can be used as a partial replacement of the aggregate for the Asphalt Concrete mixture AC-WC heat mixture with a plastic waste content is limited to a maximum of $10 \%$ and at an optimum asphalt content of 5.55\%. Thus this research is expected to be of benefit to the industry and the people of Semarang in relation to the use of plastic waste for road pavement.
\end{abstract}

Kata kunci : plastic waste, concrete asphalt substitution

\section{PENDAHULUAN}

Bahan plastik dapat dibedakan 2 golongan dasar ditinjau dari struktur molekulnya, yaitu: bahan thermoplast dimana bersifat dapat diulang-ulang untuk dilembekkan dan dikeraskan dengan jalan memanasi dan mendinginkannya, sedang jenis lainnya adalah thermosetting yang bersifat mengeras setelah dibentuk dan tidak dapat dilembekkan lagi dengan cara pemanasan. Plastik merupakan bahan yang penting dalam bidang konstruksi karena memberikan sifat yang luas dalam pemakaian, seperti: tahan korosi, tahan air, ringan, liat serta 
mudah dibentuk menjadi bentukbentuk yang sulit. Karena bahan plastik cukup banyak jenisnya, dan jenis satu dengan lainnya berbeda sifatnya serta memberikan keuntungan yang berbeda, maka bahan ini dapat dipakai sebagai bahan bangunan (PEDC, 1987)

Sekarang ini, plastik merupakan bahan yang sangat dibutuhkan oleh masyarakat luas dan dampaknya sangat luar biasa setelah plastik itu dipergunakan, yang dapat menimbulkan permasalahan serius apabila dalam pengelolaannya tidak dilakukan secara benar. Walikota Semarang pada 24 April 2016 dalam rangka sosialisai Perda No.6 Tahun 2012 menyampaikan bahwa di tingkat internasional, negara kita menduduki peringkat kedua penghasil sampah plastik setelah Tiongkok. Dari data terakhir pada tahun 2015, Indonesia menghasilkan sampah plastik mencapai 187,2 ton. Salah satu contoh penghasil sampah plastik adalah investasi swasta di bidang retail di mana jumlah gerai sebanyak 32.000 gerai yang menghasilkan sampah/kantong plastik sebanyak 9,6 juta lembar per hari. Sementara persoalan sampah sudah menjadi masalah serius di Kota Semarang sampai produksi sampah di Kota Semarang mencapai 1.200 ton/hari. Di beberapa wilayah, bahkan masalah sampah sudah menjadi persoalan yang meresahkan warga. Disamping juga akibat persoalan tempat pembuangan sampah (TPS) muncul persoalan horisontal yang mengakibatkan terpecah belahnya kerukunan warga.
Yang berarti plastik ini apabila tidak dikelola dengan baik akan menimbulkan masalah besar dikemudian hari.

Permasalahan plastik ini tidak hanya disampaikan oleh Wali Kota Semarang saja, akan tetapi juga oleh Kementerian Lingkungan Hidup dan Kehutanan sampai memberlakukan program pemakaian kantong plastik berbayar dalam jangka pendek. Hal ini untuk menangani permasalahan dalam jangka pendek saja. Namun dalam jangka panjang, justru tidak akan menyelesaikan permasalahan "sampah plastik", lantaran kebijakan tersebut justru mendorong masyarakat untuk membeli plastik yang sudah barang tentu akan menambah beban baru masyarakat untuk membelinya (Suara Merdeka, 2016).

Contoh permasalahan plastik tidak hanya terbatas seperti diatas saja, akan tetapi menurut Lampung Pos Minggu, 15 Mei 2016 bahwa terjadinya banjir jalan protokol di Kota Metro saat hujan turun, ternyata disebabkan tersumbatnya aliran drainase tertutup oleh sampah. Dinas Pekerjaan Umum menemukan tumpukan sampah plastik dan terjadi sendimentasi pada saluran air tertutup tersebut. Namun, kondisi itu tampaknya tidak bisa segera diatasi karena keterbatasan dana untuk membongkar trotoar keseluruhannya.

Pada perkerasan lentur (flexible pavement) dipakai material aspal sebagai bahan pengikat agregat. Dimana material aspal memiliki sifat kohesif, adhesif, dan termoplast. Sifat kohesif adalah sifat aspal yang mengikat sesama komponen aspal, 
yang dapat ditunjukkan melalui uji daktilitas, sedang adhesif adalah sifat aspal untuk mengikat material lain, yaitu agregat sehingga campuran tersebut dapat disebut dengan nama Aspal Beton atau asphalt concrete (AC).

Sekarang ini masalah yang terkait dengan Konstruksi Sipil, adalah menipisnya persediaan agregat seperti pasir, kerikil dan atau batu pecah yang dapat dikatakan semakin langka. Karena agregat tersebut tidak hanya dipergunakan untuk perkerasan jalan saja, akan tetapi juga untuk proyek konstruksi lain, seperti : pembuatan gedung-gedung bertingkat, perumahan dan bendungan yang sudah barang tentu semakin menipis.

Berdasarkan permasalahan diatas, perlu kiranya limbah plastik jenis thermosetting dimanfaatkan untuk dibuat menjadi suatu bahan bangunan seperti Aspal Beton campuran panas/Asphalt Concrete (AC), melalui penelitian dengan mengukur seberapa besar pengaruh penambahan variasi limbah plastik terhadap Specific Gravity (SG), Voids in Mix (VIM), Voids in Material Agregates (VMA), Voids Filled with Bitumen (VFB), Stability, Flow, Stabilitas Marshall sisa dan Rongga dalam Campuran (VIM) pada kepadatan membal (Refusal) atau dikenal dengan parameter Marshall. Dalam penelitian ini dibuat Aspal Beton campuran panas dengan penambahan 5 variasi campuran mulai dari (2 s.d. 10)\% terhadap berat campuran.
Penelitian ini dimaksudkan untuk mengukur pengaruh 5 variasi penambahan limbah plastik terhadap campuran Aspal Beton campuran panas yang diukur dari parameter Marshall yang diperoleh. Sedang tujuan yang ingin dicapai adalah dengan penambahan 5 variasi limbah plastik pada campuran yang dimulai dari (2 s.d. 10)\% terhadap berat campuran, akan mempunyai pengaruh terhadap sifat Aspal Beton yang memenuhi persyaratan umum dalam Spesifikasi Umum 2018 Bidang Jalan dan Jembatan. Hasil penelitan diharapkan dapat dimanfaatkan untuk bahan Konstruksi Perkerasan Jalan khususnya perkerasan lentur (flexible pavement) disamping dapat membantu memecahkan persoalan sampah yang serius dimasyarakat.

Untuk mewujudkan bahwa limbah plastik dapat dibuat Aspal Beton campuran panas, sehingga pemerintah Kota Semarang sebagai pengambil kebijakan dan industri yang bergerak dalam bidang pengadaan Aspal Beton campuran panas siap hampar dapat memanfaatkan limbah plastik ini untuk dibuatnya. Oleh karena itu dimasa yang akan datang dibutuhkan kerjasama semua pihak, diantaranya (1) Perguruan tinggi seperti Polines ini sebagai institusi yang mempunyai kewajiban untuk melakukan Tri Darma Perguruan tinggi melalui kegiatan penelitian dan pengabdian kepada masyarakat, (2) Pemerintah Kota Semarang sebagai penanggung jawab pemerintahan Daerah dan pengambil kebijakan, dan (3) Masyarakat kota Semarang sebagai 
masyarakat social yang dalam kehidupan sehari-hari tidak lepas dari permasalahan sampah plastik dapat teratasi dari permasalahannya.

Penelitian-penelitian terdahulu yang terkait adalah sebagai berikut:

a. Anita Rahmawati dan Rama Rizana, 2013, telah melakukan penelitian berjudul Pengaruh penggunaan limbah plastik polipropilena sebagai Pengganti agregat pada campuran laston terhadap Karakteristik marshall, dalam penelitiannya memberikan gambaran pengaruh penggunaan limbah plastik dengan kadar $0 \%, 2 \%, 5 \%$, dan $10 \%$ pada campuran laston;

b. Ida Bagus Wirahaji, 2012, melakukan penelitian dengan judul Analisis kadar aspal optimum laston lapis aus pada ruas jalan Simpang Sakah - Simpang Blahbatuh, hasil pemeriksaan menunjukkan Percentage Refusal Density (PRD) diperoleh hasil nilai VIM sebesar 4.84\%. Semua nilai karakteristik campuran AC-WC pada kadar aspal $6.80 \%$ memenuhi persyaratan sepesifkasi teknik 2010.

\section{METODE PENELITIAN}

Tahapan penelitian diatas dapat dibagi dalam 3 (tiga) tahap, antara lain mulai dari menganalisis material bahan susun sampai dengan menyusun proporsi dan menguji Aspal Beton campuran panas dari beberapa parameter Marshall. Aspal Beton campuran panas dibuat dari bahan Agregat kasar, agregat halus dan filler terdiri dari 6 seri dengan setiap seri beda 0,50\% kemudian diuji Specific Gravity (SG),
Voids in Mix (VIM), Voids in Material Agregates (VMA), Voids Filled with Bitumen (VFA), Stability, dan Flow untuk ditentukan Kadar Aspal Optimumnya dan kemudian dibuat benda uji pada Kadar Aspal Optimum dengan ditambah dengan 5 variasi proporsi campuran Aspal Beton campuran panas tanpa limbah plastik (BN), Aspal Beton campuran panas dengan limbah plastik 2\% (B2); $4 \%$ (B4); 6\% (B6); 8\% (B8) dan $10 \%$ (B10), semua bahan dalam kondisi kering oven.

Sebagai pedoman dalam pembuatan campuran (mix design) menggunakan SNI 06-2489-1991 yaitu Metode Pengujian Campuran Aspal Dengan Alat Marshall. Atau penelitian ini dilakukan dalam tahapan sebagai berikut :

(1) Tahap I : Menguji sifat fisis dan mekanis bahan susun Aspal Beton campuran panas, seperti : pasir, batu pecah dan aspal;

(2) Tahap II : Perhitungan rencana campuran (Mix Design). Metode perhitungan menggunakan cara yang terdapat dalam SNI 06-24891991. Dalam penelitian ini akan dilakukan mix design untuk mendapatkan komposisi bahan susun Aspal Beton campuran panas. Hasil mix design selanjutnya dibuat benda uji Aspal Beton campuran panas terdiri dari 6 seri dengan setiap seri beda $0,50 \%$ untuk ditentukan Kadar Aspal Optimumnya dari nilai Density/Specific Gravity (SG), Voids in Mix (VIM), Voids in Material Agregates (VMA), Voids 
Filled with Bitumen (VFA), Stability, dan Flow;

(3) Tahap III : Uji eksperimental Density/Specific Gravity (SG), Voids in Mix (VIM), Voids in Material Agregates (VMA), Voids Filled with Bitumen (VFA), Stability, dan Flow sejumlah benda Aspal Beton campuran panas dengan berbagai variasi limbah plastik setiap beda $2 \%$ terhadap berat campuran.

Bahan-bahan yang dipakai dalam penelitian ini adalah aspal keras, jenis $\begin{array}{llll}\text { Pen } & 60 \text { ex produksi P.T. }\end{array}$ PERTAMINA, Agregat halus (pasir), pasir yang dipakai dalam penelitian ini adalah pasir Muntilan; serta agregat kasar (splite), split yang dipakai dalam penelitian ini adalah batu pecah dari Gunung Pati.

Alat-alat yang dipergunakan dalam penelitian ini meliputi peralatan uji di Laboratorium Teknik Sipil Politeknik Negeri Semarang (Polines), Jl. Prof. Sudarto, S.H. Tembalang Kotak Pos 6199/SMS Semarang Telpon (024) 74734177499585,7499586,7499587 (hunting), dengan menggunakan peralatan yang ada dan jenis peralatan yang sesuai dengan jenis pengujiannya, antara lain alat uji agregat, alat uji aspal, dan alat uji karakteristik campuran beton aspal.

\section{Pengumpulan data}

Data penelitian diambil dari hasil pemeriksaan dilaboratorium terhadap bahan aspal, agregat halus, agregat kasar. Selanjutnya, dengan membuat 5 variasi proporsi campuran Aspal Beton campuran panas tanpa limbah plastik
(BN), Aspal Beton campuran panas dengan limbah plastik 2\% (B2); $4 \%$ (B4); 6\% (B6); $8 \%$ (B8) dan 10\% (B10), dianalisa Kepadatan (density), nilai Rongga dalam campuran (VIM), nilai Rongga diantara Mineral Agregat (VMA), Rongga terisi aspal (VFA), Stabilitas Marshall (MS), Kelelehan (Flow). Untuk mengetahui sejauhmana pengaruh penambahan limbah platik terhadap parameter Marshall, perlu diuji masing-masing campuran dan dianalisis mulai dari tanpa sampai dengan penambahan limbah platik parameter Marshall (Density, Stabilitas; kelelehan; kepadatan VIM; $V M A$ dan VFA) dengan setiap parameter Marshall terdapat batas minimal dan maksimum, kemudian digambar hubungan antara jenis campuran dengan parameter Marshall dalam bentuk tabel maupun kurva.

\section{Analisis data}

Analisa dilakukan terhadap pengaruh tanpa penambahan limbah plastik dengan penambahan limbah plastik terhadap parameter Marshall yaitu nilai Density, nilai Rongga dalam campuran (VIM), nilai Rongga diantara Mineral Agregat (VMA), Rongga terisi aspal (VFA), Stabilitas Marshall (MS), Kelelehan (Flow). Hasilnya dibandingkan terhadap spesifikasi standard yaitu Spesifikasi Umum Bidang Jalan dan Jembatan 2010 edisi revisi 3.

\section{HASIL DAN PEMBAHASAN Hasil Pengujian}

Pengujian material dilakukan dengan menggunakan acuan standar uji 
Standar Nasional Indonesia (SNI) atau ASTM (jika pada salah satu diantara jenis uji tertentu tidak terdapat dalam $\mathrm{SNI}$ ), pengujian sifat - sifat material meliputi : Abu batu, Batu Pecah, dan Aspal Keras dengan hasil seperti dalam tabel 1.

Tabel 1. Hasil penelitian sifat fisik dan mekanis agregat

\begin{tabular}{|c|l|c|c|c|c|}
\hline No & \multicolumn{1}{|c|}{ Jenis material } & Standar & $\begin{array}{c}\text { Hasil } \\
\text { pengujian }\end{array}$ & Spesifikasi & Keterangan \\
\hline 1 & Abu Batu & & & & \\
\hline a & Analisa ayak & SNI ASTM C136:2012 & & & lihat lampiran \\
\hline b & Nilai Setara Pasir & SNI 03-4428-1997 & 98,17 & Min. 60\% & \\
\hline c & Gumpalan Lempung \& Butir mudah pecah & SNI 03-4142-1996 & 0,69 & Maks. 1\% & \\
\hline d & Material lolos ayakan no. 200 & SNI ASTM C117 :2012 & 3,86 & Maks. 10\% & \\
\hline 2 & Batu pecah 1/2 & & & & \\
\hline a & Analisa ayak & SNI ASTM C136: 2012 & & & lihat lampiran \\
\hline b & Kekekalan bentuk terhadap larutan NaSO4 & SNI 3407-2008 & 0,14 & Maks. 12\% & \\
\hline c & Abrasi dengan metode Los Angeles & SNI 2417 -2008 & 12,52 & Maks. 30\% & \\
\hline d & Kelekatan Agregat terhadap Aspal & SNI 2439-2011 & 97,90 & Min. 95\% & \\
\hline e & Butir Pecah pada Agregat Kasar & SNI 7619-2012 & $98,21 / 95,49$ & $95 / 90$ & \\
\hline f & Pipih dan lonjong & ASTM D4791 & 9,71 & Maks. 10\% & \\
\hline g & Material lewat saringan no. 200 & SNI ASTM C117 :2012 & 0,39 & Maks. 2\% & \\
\hline
\end{tabular}

Tabel 2. Hasil uji Parameter Marshall Untuk Berbagai Jenis Campuran

\begin{tabular}{|c|c|c|c|c|c|c|}
\hline \multirow{2}{*}{$\begin{array}{c}\text { Kadar Aspal } \\
(\%)\end{array}$} & \multicolumn{6}{|c|}{ Density (ton $/ \mathrm{m}^{3}$ ) } \\
\hline & BN & B2 (2\%) & B4 (4\%) & $\mathrm{B} 6(6 \%)$ & B8 (8\%) & B10 (10\%) \\
\hline 5,55 & 2,091 & 2,108 & 2,110 & 2,111 & 2,113 & 2,119 \\
\hline Kadar Aspal & \multicolumn{6}{|c|}{ Stabilitas Marshall (kg) } \\
\hline (\%) & BN & B2 (2\%) & B4 (4\%) & B6 (6\%) & B8 (8\%) & B10 (10\%) \\
\hline 5,55 & $1.087,76$ & $1.257,52$ & $1.361,10$ & $1.343,96$ & $1.445,32$ & $1.442,07$ \\
\hline Kadar Aspal & \multicolumn{6}{|c|}{ Kelelehan $(\mathrm{mm})$} \\
\hline (\%) & BN & B2 (2\%) & B4 (4\%) & B6 (6\%) & B8 (8\%) & B10 (10\%) \\
\hline 5,55 & 2,93 & 3,19 & 3,32 & 3,43 & 3,45 & 3,93 \\
\hline Kadar Aspal & \multicolumn{6}{|c|}{ VIM (\%) } \\
\hline (\%) & BN & B2 (2\%) & B4 (4\%) & B6 (6\%) & B8 (8\%) & B10 (10\%) \\
\hline 5,55 & 4,56 & 3,77 & 92 & 3,96 & 11 & 4,65 \\
\hline Kadar Aspal & \multicolumn{6}{|c|}{ VMA (\%) } \\
\hline (\%) & BN & B2 (2\%) & B4 (4\%) & B6 (6\%) & B8 (8\%) & 6) $\mathrm{B} 10(10 \%$ \\
\hline 5,55 & 25,58 & 24,97 & 25,09 & 25,12 & 25,23 & 25,65 \\
\hline Kadar Aspal & \multicolumn{6}{|c|}{ VFA (\%) } \\
\hline (\%) & $\mathrm{BN}$ & B2 (2\%) & B4 (4\%) & $\mathrm{B} 6(6 \%)$ & B8 (8\%) & B10 (10\%) \\
\hline 5,55 & 82,19 & 84,89 & 84,38 & 4,24 & 83,74 & 81,90 \\
\hline Kadar Aspal & \multicolumn{6}{|c|}{$M Q(\mathrm{~kg} / \mathrm{mm})$} \\
\hline (\%) & BN & B2 (2\%) & B4 (4\%) & B6 (6\%) & B8 (8\%) & B10 (10\%) \\
\hline 5,55 & 371,25 & 394,21 & 410,59 & 477,73 & 419,54 & 365,54 \\
\hline Kadar Aspal & \multicolumn{6}{|c|}{ Stabilitas Marshall sisa (kg) } \\
\hline (\%) & BN & B2 (2\%) & B4 (4\%) & $\mathrm{B} 6(6 \%)$ & B8 (8\%) & B10 (10\%) \\
\hline 5,55 & $1.050,89$ & $1.153,12$ & $1.306,53$ & $1.327,70$ & $1.391,44$ & \begin{tabular}{|l|l|}
4 & $1.360,42$ \\
\end{tabular} \\
\hline Kadar Aspal & \multicolumn{6}{|c|}{ VIMrefusal Density (\%) } \\
\hline$(\%)$ & $\mathrm{BN}$ & B2 (2\%) & B4 (4\%) & $\mathrm{B} 6(6 \%)$ & B8(8\%) $\quad$ B & B10 (10\%) \\
\hline 5,55 & 2,73 & 2,64 & 2,56 & 2,46 & 2,35 & 2,19 \\
\hline
\end{tabular}




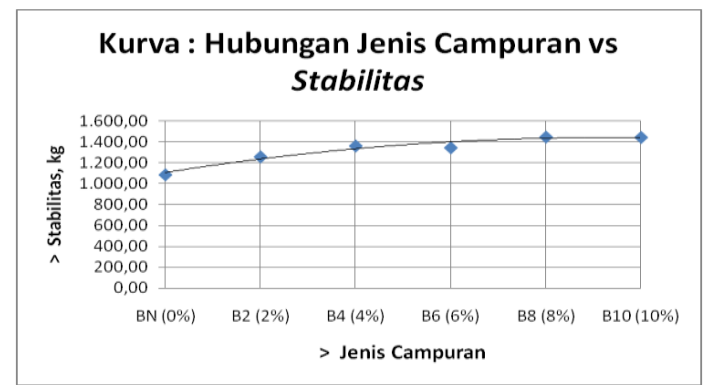

a. Hubungan Jenis Campuran dengan Stabilitas Marshall

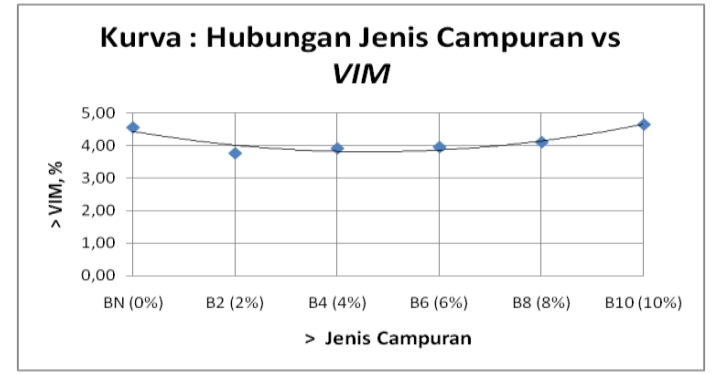

c. Hubungan Jenis Campuran dengan VIM

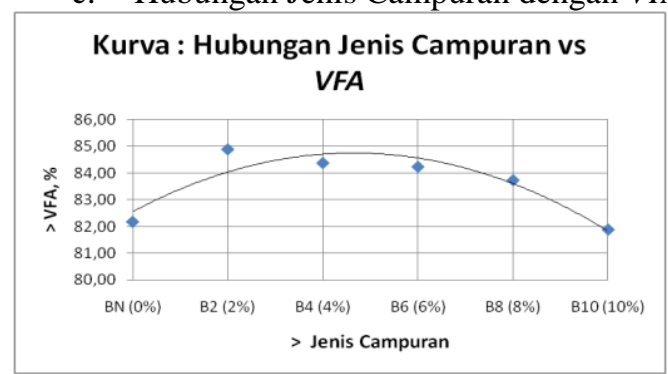

e. Hubungan Jenis Campuran dengan VFA Kurva : Hubungan Jenis Campuran vs Stabilitas Marshall sisa

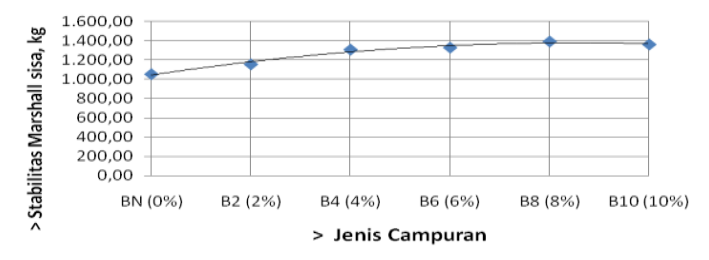

g. Hubungan Jenis Campuran dengan Stabilitas Marshall sisa

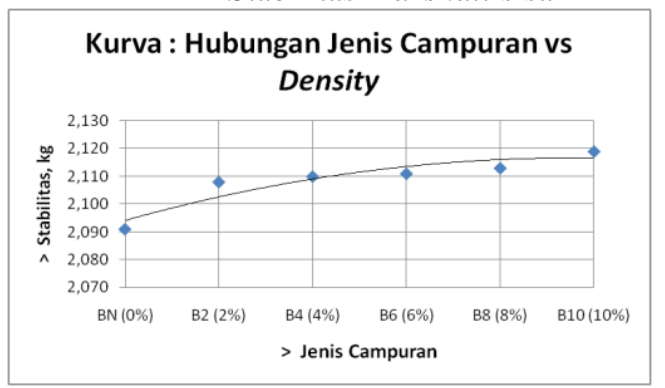

i. Hubungan Jenis Campuran dengan Density

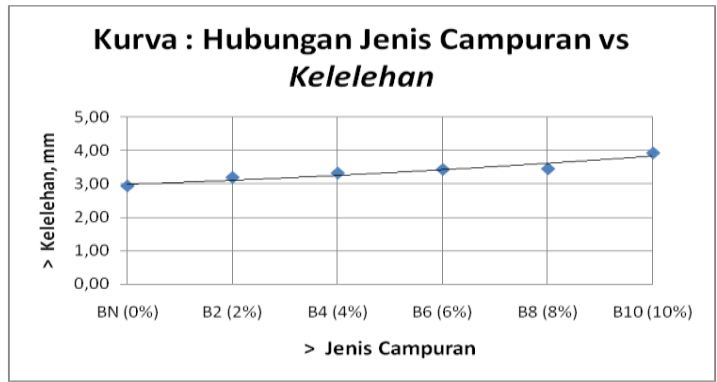

b. Hubungan Jenis Campuran dengan Kelelehan

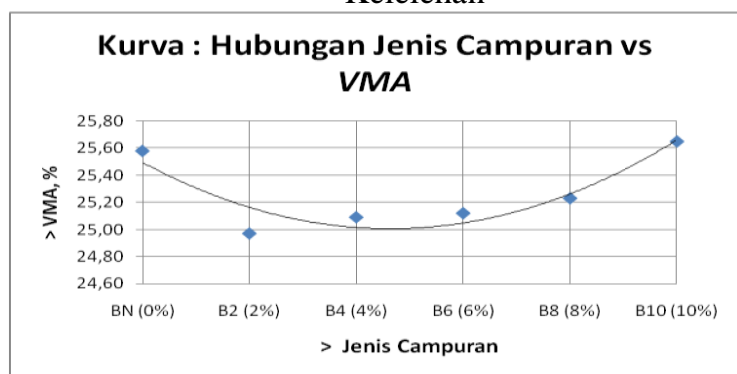

d. Hubungan Jenis Campuran dengan VMA

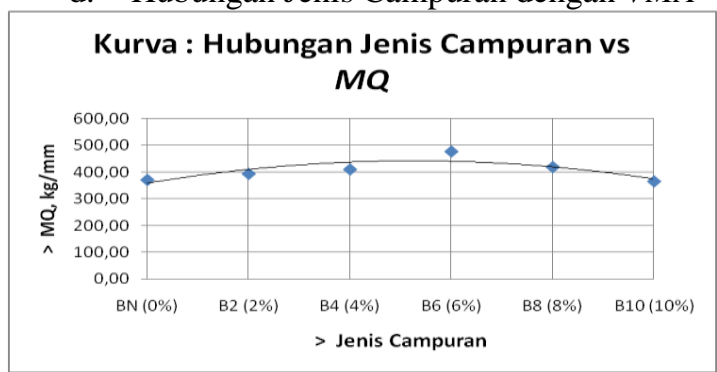

f. Hubungan Jenis Campuran dengan $M Q$

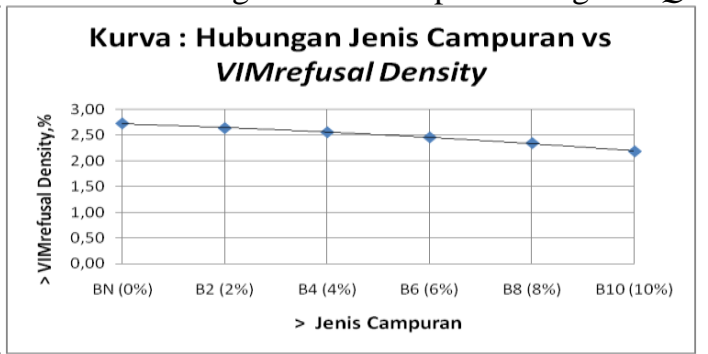

h. Hubungan Jenis Campuran dengan VIMrefusal density

Gambar 1. Hubungan Jenis Campuran dengan Parameter Marshall 
Dengan hasil pengujian material agregat yang berasal dari Abu Batu dan Batu Pecah seperti di atas, maka agregat tersebut dinyatakan "dapat digunakan" sebagai Bahan susun Aspal beton campuran panas dalam penelitian ini menggunakan batu pecah dari Gunung Pati. Abu Batu dan Batu Pecah dinyatakan dapat dipergunakan untuk campuran Aspal beton campuran panas dan dari semua hasil pengujian sifat fisik/mekanis menunjukkan memenuhi persyaratan seperti yang terdapat dalam Spesifikasi Umum Bidang Jalan dan Jembatan 2010 edisi revisi 3.

Dari uji Analisa ayak agregat Abu batu dan Batu pecah, dengan komposisi campuran yang semua prosentase lolos komulatipnya berada dalam titik kontrol atas dan titik kontrol bawah (lihat lampiran pengujian material agregat). Secara umum agregat yang "dipergunakan" dalam penelitian dapat dipergunakan untuk Aspal beton campuran panas, karena ditinjau secara garis besar persyaratan fisik dan mekanis dapat dinyatakan memenuhi persyaratan sebagai agregat (lihat tabel 1).

Aspal keras dalam penelitian ini menggunakan aspal jenis Pen 60 ex produksi P.T. PERTAMINA dan didapat hasil uji seperti tabel $4.2 \mathrm{di}$ bawah. Jadi aspal keras Pen 60/70 produk Pertamina dapat dipergunakan dalam penelitian Aspal beton campuran panas yang dicampur dengan plastik, karena ditinjau secara garis besar persyaratan fisik dapat dinyatakan memenuhi persyaratan sebagai perekat.

\section{Pembahasan}

Hasil pengujian parameter Marshall dengan berbagai macam jenis campuran (penambahan limbah plastik) dapat dilihat seperti dalam tabel 2. Campuran mulai dari tanpa penambahan Plastik sampai dengan campuran setiap beda $2 \%$ mulai dari $2 \%$ sampai dengan $10 \%$.

\section{Hubungan antara Jenis Campuran dengan Density}

Density adalah perbandingan berat massa aspal beton campuran panas dengan berat air pada volume yang sama dan suhu tertentu yang dinyatakan dalam satuan ton $/ \mathrm{m}^{3}$. Density mempunyai pengaruh secara linier terhadap nilai Stabilitas. Nilai Density untuk masing-masing variasi campuran dapat dilihat pada Tabel 2 dan Gambar 1i.

Gambar Hubungan Jenis Campuran dengan Density dapat menunjukkan bahwa semua variasi dengan menggunakan campuran limbah plastik. Dari berbagai variasi kadar aspal dapat dilihat bahwa dengan peningkatan Persentase penggunaan limbah plastik mempunyai kecenderungan nilai Density-nya naik. Hal ini disebabkan oleh karena limbah plastik pada saat pencampuran dan pemadatan sebagian ada telah mengalami lembek, sehingga dapat mempengaruhi ikatan antar agregatnya menjadi semakin kuat yang pada akhirnya dapat mempengaruhi Density 
menjadi tinggi. Density tertinggi dicapai pada campuran dengan kadar aspal $10 \%$, yakni sebesar 2,119 ton $/ \mathrm{m}^{3}$, dan nilai Density terendah pada campuran penambahan kadar plastik $2 \%$ dengan nilai Density 2,108 ton $/ \mathrm{m}^{3}$.

\section{Hubungan antara Jenis Campuran dengan Stabilitas. \\ Stabilitas Marhall adalah beban} maksimum yang dapat ditanggung oleh benda uji pada suhu $60^{\circ} \mathrm{C}\left(140^{\circ} \mathrm{F}\right)$ dinyatakan dalam satuan beban gaya (kg atau pound). Stabilitas merupakan salah satu parameter Marshall untuk mengukur ketahanan terhadap kelelehan plastis dari suatu campuran aspal beton atau dapat dikatakan kemampuan campuran untuk menahan deformasi yang terjadi akibat beban lalu lintas yang bekerja. Nilai Stabilitas Marshall untuk masing-masing variasi campuran dapat dilihat pada Tabel 2 dan Gambar 1a.

Gambar 1a di atas menunjukkan bahwa semua variasi yang menggunakan tambahan limbah plastik memenuhi persyaratan dalam Spesifikasi Umum Bidang Jalan 2010 edisi revisi 3. Dengan berbagai variasi kadar limbah plastik dapat menunjukkan kecenderungan nilai stabilitas meningkat. Hal ini dapat saja terjadi karena limbah plastik pada saat pencampuran dan pemadatan sebagian plastik telah mengalami kelelehan, sehingga ikatan antara agregat satu dengan lainnya menjadi semakin kuat yang dapat mempunyai pengaruh terhadap nilai stabilitas tinggi. Stabilitas tertinggi dicapai oleh campuran dengan kadar aspal 8\% yakni sebesar 1.445,32 kg, sedangkan nilai Stabilitas terendah pada campuran penambahan kadar plastik 2\% dengan nilai Stabilitas $1.257,52 \mathrm{~kg}$

\section{Hubungan antara Jenis Campuran} dengan Kelelehan.

Harga kelelehan atau flow adalah jumlah gerakan atau deformasi/penurunan akibat pembebanan, dihitung dalam unit = $1 / 100 \mathrm{~mm}$ pada pembebanan maksimum untuk menentukan Stabilitas Marshall. Kelelehan ini dapat dipengaruhi oleh faktor-faktor, antara lain : gradasi agregat, susunan dan bentuk permukaan agregat serta kadar aspal. Hasil kelelehan dalam pengujian ini ditunjukkan dalam Tabel 2 dan Gambar 1b.

Gambar 1b memperlihatkan bahwa dengan penambahan limbah plastik kedalam campuran Aspal beton dapat meningkatkan nilai kelelehan. Semakin banyak penambahan limbah plastik, nilai kelelehan benda uji semakin tinggi nilainya. Nilai kelelehan tertinggi terjadi pada penambahan $10 \%$ sebesar 3,93 $\mathrm{mm}$, dan nilai terendah pada campuran tanpa penambahan limbah plastik 2\%, yaitu sebesar 3,19 mm. Dengan semakin banyak penambahan limbah plastik, semakin tinggi pula nilai kelelehannya. Ini dapat terjadi karena sebagian limbah plastik telah mengalami leleh pada saat pencampuran dan pemadatan, sehingga ada sebagian limbah plastik akan mengisi rongga-rongga antar agregat yang dapat mempengaruhi rongga 
udaranya semakin kecil, dan kepadatan campuran semakin meningkat. Peningkatan nilai kelelehan terjadi hingga pada penambahan limbah plastik $10 \%$.

\section{Hubungan antara Jenis Campuran dengan VIM}

Persen rongga atau VIM adalah presentase volume rongga terhadap volume total campuran setelah dipadatkan yang dinyatakan dalam persen. Nilai VIM akan mengalami penurunan sehubungan dengan penambahan kadar aspal, sehingga rongga udara dalam campuran dapat menjadi minimum. Hasil nilai VIM dapat dilihat pada Tabel 2 dan Gambar $1 c$.

Gambar 1c menunjukkan nilai VIM kecenderungan meningkat sehubungan dengan penambahan limbah plastik. Nilai VIM mempunyai pengaruh terhadap sifat ketahanan lama (durability), karena semakin besar nilai VIM berarti campuran bersifat keropos (porous). Rongga udara ini dapat menyebabkan air mudah masuk ke dalam lapis perkerasan sehingga dapat mengakibatkan meningkatnya proses oksidasi yang akhirnya dapat mempercepat proses pelapukan aspal. Berkaitan hal tersebut dalam Spesifikasi Umum Bidang Jalan dan Jembatan membatasi nilai VIM berada antara $3,0 \%-5,0 \%$. Nilai VIM tertinggi penambahan limbah plastik $10 \%$, sebesar $4,65 \%$, sedangkan nilai terendah pada penambahan limbah plastik $2 \%$ sebesar $3,77 \%$.
Hubungan antara Jenis Campuran dengan VMA

$V M A$ adalah rongga di antara agregat yang dinyatakan dalam persen. VMA mempunyai peranan penting untuk membuat ruang yang cukup bagi aspal beton agar supaya campuran mempunyai durabilitas yang tinggi. Jika nilai $V M A$ terlalu besar, maka akan dibutuhkan aspal dalam jumlah yang berlebihan untuk mengurangi rongga udara, sehingga harus sesuai dengan yang disyaratkan dan dalam Spesifikasi Umum Bidang Jalan dan Jembatan 2010 edisi revisi 3 membatasi untuk Laston AC-WC kurang dari $15 \%$.

$V M A$ atau yang lebih dikenal dengan rongga diantara butir agregat merupakan salah satu parameter penting dalam perancangan campuran aspal, karena pengaruhnya terhadap ketahanan lama dari campuran aspal beton. VMA dapat menunjukkan banyaknya aspal dari rongga yang terisi aspal (dalam persen). Pengaruh nilai hasil pengujian VMA dengan penambahan limbah plastik ini dapat dilihat pada Tabel 2 dan Gambar 1d.

Disyaratkan harus mempunyai nilai minimum adalah untuk menghindari banyaknya rongga udara yang menyebabkan material menjadi banyak pori. Rongga pori diantara mineral agregat dipengaruhi oleh : ukuran maksimum besar butir, susunan dan bentuk permukaan dan metode pemadatan. Nilai VMA akan naik secara signifikan sebagai akibat dari penambahan dan penggantian bahan pengisi. Dari Tabel 2 dan Gambar 1e dapat dilihat bahwa nilai $V M A$ 
cenderung meningkat sejalan dengan penambahan limbah plastik. Nilai $V M A$ tertinggi dicapai pada penambahan limbah plastik $10 \%$ dan sebesar $25,65 \%$, sedangkan nilai terendah pada penambahan limbah plastik $2 \%$ sebesar $24,97 \%$.

\section{Hubungan antara Jenis Campuran dengan VFA}

Nilai $V F A$ dapat ditentukan dari jumlah $V M A$ dan rongga udara di dalam campuran (VIM). VFA adalah persentase dari VMA yang terisi oleh aspal, tidak termasuk aspal yang diserap oleh agregat. Nilai $V F A$ akan bertambah besar dengan penambahan kadar aspal. VIM atau rongga dalam campuran dapat terjadi sebagai akibat adanya ruang sisa yang dibentuk antar butiran penyusun campuran. Rongga ini dalam kondisi kering akan diisi uk oleh udara dan kalau dalam kondisi basah akan diisi air. Sehingga bersifat alkalis, udara dan air akan mempercepat proses oksidasi dan dilanjutkan pelarutan aspal dalam campuran. Akibatnya dalam jangka panjang, campuran akan mengalami membentuk residu. Hasil nilai VFA dapat dilihat pada Tabel 2 dan Gambar 1e di atas.

Nilai VFA cenderung mengalami penurunan seiring dengan penambahan limbah plastik dalam campuran Aspal beton. Penurunan VFA yang terjadi, dikarenakan dengan penambahan limbah plastik yang akan mengakibatkan semakin banyaknya limbah plastik yang mengalami kelelehan dan masuk ke dalam rongga yang ada, sehingga aspal yang digunakan menjadi berlebihan dan dapat menyebabkan terjadinya bleeding. Nilai VFA tertinggi pada campuran dengan penambahan limbah plastik 2\% yakni sebesar 84,89\%, sedangkan nilai VFA terendah pada campuran dengan penambahan limbah plastik $10 \%$ dengan $V F A$ sebesar $81,90 \%$.

\section{Hubungan antara Jenis Campuran dengan Marshall Quotion}

$M Q$ adalah hasil bagi Stabilitas Marshall dengan kelelehan yang dinyatakan dalam satuan $\mathrm{kg} / \mathrm{mm}$. Hal ini dipergunakan untuk pendekatan terhadap tingkat kekakuan atau kelenturan aspal beton. Nilai $M Q$ merupakan pendekatan terhadap tingkat kekakuan dan fleksibel suatu campuran. Campuran dengan nilai $M Q$ rendah dapat dikatakan bahwa campuran aspal beton bersifat fleksibel dan kecenderungan mudah mengalami perubahan bentuk (deformasi) yang besar pada saat menerima beban dan sebaliknya jika nilai $M Q$ tinggi. Hasil untuk pengujian $M Q$ tersebut dapat dilihat pada Tabel 2 dan Gambar 1f.

$M Q$ yang dianalisa sebagai rasio dari stabilitas terhadap kelelehan yang digunakan sebagai indikator untuk menentukan kekakuan aspal beton. Nilai $M Q$ yang disyaratkan Spesifikasi Umum Bidang Jalan dan Jembatan 2010 edisi revisi 3, adalah $250 \mathrm{~kg} / \mathrm{mm}$. Nilai $M Q$ tertinggi pada campuran dengan penambahan limbah plastik $6 \%$ yakni sebesar $477,73 \mathrm{~kg} / \mathrm{mm}$, sedangkan nilai $M Q$ terendah pada campuran dengan penambahan limbah 
plastik $10 \%$ dengan $M Q$ sebesar $365,54 \mathrm{~kg} / \mathrm{mm}$

\section{Hubungan antara Jenis Campuran dengan Stabilitas Marshall sisa}

Stabilitas Marshall sisa adalah kemampuan benda uji dalam menerima beban maksimum pada suhu $60^{\circ} \mathrm{C}$ dari benda uji direndam selama 24 jam sampai terjadinya perubahan bentuk yang dinyatakan dalam prentase terhadap Stabilitas Marshall (\%). Dalam hal ini disyaratkan harus mempunyai nilai Stabilitas Marshall minimum 90\%. Hal ini dipergunakan untuk pendekatan kemampuan aspal beton campuran panas dalam kondisi terendam selama 24 jam masih mempunyai kekuatan 90\%. Hasil untuk pengujian Stabilitas Marshall sisa tersebut dapat dilihat pada Tabel 2 dan Gambar 1g.

Gambar 1g di atas menunjukkan bahwa dengan berbagai variasi kadar limbah plastik dapat menunjukkan kecenderungan nilai Stabilitas Marshall sisa meningkat. Stabilitas Marshall sisa tertinggi dicapai pada campuran dengan kadar aspal 8\% yakni sebesar 1.391,44 kg, sedangkan nilai Stabilitas terendah pada campuran penambahan kadar plastik 2\% dengan nilai Stabilitas 1.153,12 kg.

\section{Hubungan antara Jenis Campuran dengan VIM pada Refusal Density}

Persen rongga atau VIM adalah presentase volume rongga terhadap volume total campuran setelah dipadatkan yang dinyatakan dalam persen. Nilai VIMrefusal density akan mengalami penurunan sehubungan dengan pemadatan sebanyak 400 kali perbidang dan dengan penambahan limbah plastik, kadar aspal, sehingga rongga udara dalam campuran dapat menjadi rendah. Hasil nilai VIMrefusal density dapat dilihat pada Tabel 2 dan Gambar 1h.

Gambar 1h menunjukkan nilai VIMrefusal density kecenderungan menurun sehubungan dengan penambahan limbah plastik. Berkaitan VIMrefusal density dalam Spesifikasi Umum Bidang Jalan dan Jembatan membatasi nilai VIMrefusal density minimal dibatasi tidak boleh kurang dari 2,0 \%. Nilai VIMrefusal density tertinggi pada penambahan limbah plastik $2 \%$, sebesar $2,64 \%$, sedangkan nilai terendah pada penambahan limbah plastik $10 \%$ sebesar $2,19 \%$

\section{SIMPULAN}

Berdasarkan hasil analisa dan pembahasan diatas, maka dapat disimpulkan bahwa penggunaan limbah plastik jenis Thermosetting pada pembuatan campuran Laston $A C$ $W C$ terhadap berbagai parameter Marshall antara lain, adalah : Density, Stabilitas Marshall, Kelelehan (Flow), VIM, VMA, MQ dan Stabilitas Marshall sisa cenderung mengalami peningkatan, sedangkan nilai $V F A$ dan VIMrefusal Density cenderung mengalami penurunan. Sehingga limbah plastik dari jenis Thermosetting dapat dipergunakan sebagai pengganti sebagian agregat untuk campuran Lapis Aspal Beton (Laston $A C$-WC) dalam kadar limbah plastik $0 \%, 2 \%$, 
$4 \%, 6 \%, 8 \%$ dan $10 \%$ pada kadar aspal optimum $5,55 \%$.

\section{UCAPAN TERIMA KASIH}

Penulis mengucapan terima kasih kepada : (a) Direktorat Jenderal Pendidikan Tinggi yang telah berkenan menyetujui dan memberikan dukungan dana guna penyelesaian penelitian ini, (b). Direktur Politeknik Negeri Semarang (Polines) yang telah membantu penelitian kami dengan dana DIPA Polines TA. 2019. (c) Kepala Unit Penelitian dan Pengabdian kepada Masyarakat Polines dan seluruh Staf yang terkait yang telah membantu memberi informasi pelaksanaan penelitian. (d). Seluruh Anggota Tim Peneliti, atas kerjasama, diskusi, saran, dan masukkannya sehingga kajian ini dapat berjalan dengan lancar. (e) Ketua Laboratorium Bahan Bangunan Jurusan Teknik Sipil Politeknik Negeri Semarang yang telah merekomendasi penggunakan peralatan laboratorium dan memfasilitasi segala keperluan pelaksanaan dan, (f). Tenaga laboran Lab. Bahan Bangunan Polines, anggota tim pengkaji dan semua pihak yang telah membantu hingga penelitian.

\section{DAFTAR PUSTAKA}

AASHTO, 1998,

Standard

Specifications for Transfortation

Materials and Methods of Sampling and Testing, Part I, Specifications, Nineteenth

Edition, Washington D.C

AASHTO, 1998, Standard

Specifications for Transfortation

Materials and Methods of
Sampling and Testing, Part II, Test, Nineteenth Edition, Washington D.C

ASTM, 2005, Annual Book of ASTM Standards, Vol.04.02, Concrete and Aggregates, Philadelphia, ASTM

ASTM, 2005, Standard Test for Road and Paving Materials. American Society for Testing and Materials International, Vol. 04 No. 03, West Conshohocken

Anita Rahmawati dan Rama Rizana, 2013, Pengaruh penggunaan limbah plastik polipropilena sebagai Pengganti agregat pada campuran laston terhadap Karakteristik Marshall, Konferensi Nasional Teknik Sipil 7 (KoNTekS 7), UNS Surakarta

Anto Dajan, 1996, Pengantar Statistik Jilid II, Lembaga Penelitian Pendidikan dan Penerangan Ekonomi dan Sosial, Jakarta

Departemen KIMPRASWIL, Badan Penelitian dan Pengembangan Wilayah, Badan Penelitian dan Pengembangan Kimpraswil, Standar Nasional Indonesia, 2002, Metode, Spesifikasi dan Tata Cara Bagian 2: Batuan Sedimen, Agregat, Departemen Kimpraswil, Jakarta

Departemen KIMPRASWIL, Badan Penelitian dan Pengembangan Wilayah, Badan Penelitian dan Pengembangan Kimpraswil, Standar Nasional Indonesia, 2002, Metode, Spesifikasi dan Tata Cara Bagian 3: Beton, Semen, Perkerasan Beton Semen, Departemen Kimpraswil, Jakarta 
Departemen

KIMPRASWIL,

Balitbang Kimpraswil, Standar

Nasional Indonesia, 2002,

Metode, Spesifikasi dan Tata

Cara Bagian 4: Aspal, Aspal

Batu Buton (Lasbuton),

Perkerasan Jalan, Departemen

Kimpraswil, Jakarta

Departemen PU, Balitbang PU, 2007,

Spesifikasi Campuran Beraspal

Panas, Departemen Pekerjaan

Umum, Jakarta

Ghozali, Imam, 2009, Aplikasi Analisis

Multivariate dengan program

SPSS, Cetakan IV, Badan

Penerbit Universitas Diponegoro,

Semarang

Harold N. Atkins, 1996, Highway

Materials, Soils and Concretes,

$3^{\text {th }}$ Edition Prentice Hall, New

Jersey

Kementerian PUPR, Direktorat

Jenderal Bina Marga, 2018,

Spesifikasi Umum 2018 untuk

Pekerjaan Konstruksi Jalan dan

Jembatan, Kementerian PUPR,

Jakarta

Kennedy, T. W, 1996, The Bottom

Line: Superpave System Works,

The Superpave Asphalt research

Program, The University of

Texas at Austin

PEDC, 1987, Teknologi Bahan 1, Departemen Pendidikan dan

Kebudayaan, Direktorat

Pendidikan Tinggi PEDC -

Bandung, Bandung
PEDC, 1987, Teknologi Bahan 3, Departemen Pendidikan dan

Kebudayaan, Direktorat

Pendidikan Tinggi PEDC -

Bandung, Bandung

Ritonga, Abdulrahman, 1987, Statistik

Terapan untuk Penelitian,

Lembaga Penerbit FE-UI, Jakarta

Shell Bitumen, 1991, The Shell

Bitumen Hand Book, Published

By Shell Bitumen, East Molesey

Serrey

Silvia Sukirman, 2003, Beton Aspal

Campuran Panas, Granit,

Bandung

The Asphalt Institute, 1993, Mix

Design Methods for Asphalt

Concrete and Other Hot-Mix

Types, Manual Series No.2 (MS

- 2), Asphalt Institute, Lexington

USA

Sampah Masalah Serius Kota

Semarang, 2016, http://Yulianto,

27 Mei 2016

Sampah Permukiman Masih

Terbengkelai, 2016,

http://Smcetak Solo Metro, 21

Mei 2016

Kebijakan Plastik Berbayar, 2016, http://Tasroh, 24 Pebruari 2016

Limbah di Sleman Didominasi Sampah

Plastik, 2016, http://Amelia

Hapsari, 02 Maret 2016

Penyebab Metro Banjir, Banyak

Sampah Plastik Menyumbat

Saluran Drainase, 2016,

http://Lampost, 15 Mei 2016 